\title{
COMPETITIVE INTERACTIONS AMONG ZOANTHIDS (CNIDARIA: ZOANTHIDAE) IN AN INTERTIDAL ZONE OF NORTHEASTERN BRAZIL
}

\author{
Emanuelle Fontenele Rabelo $^{1, *}$, Marcelo de Oliveira Soares ${ }^{2}$ and Helena Matthews-Cascon ${ }^{3}$ \\ ${ }^{1}$ Universidade Federal Rural do Semi-Árido \\ Departamento de Ciências Animais - Laboratório de Ecologia Marinha \\ (Br 110, Km 47, Bairro Presidente Costa e Silva, 59614-000 Mossoró, RN, Brasil) \\ ${ }^{2,3}$ Universidade Federal do Ceará - Instituto de Ciências do Mar \\ (Av. da Abolição, 3207, 60165-081, Fortaleza, CE, Brasil) \\ *Corresponding author: rabelo.ef@ufersa.edu.br
}

\begin{abstract}
A B S TRACT
Sessile organisms that live in consolidated substrates frequently compete for space. Coral species have many strategies to face this competition, including harming their opponents or hindering their growth. In the present study, the competitive interactions between three species of zoanthids were investigated in the intertidal zone of a sandstone reef environment in northeastern Brazil. The competitive abilities of the three species were evaluated by periodic observation of the natural fringes of contact and experimental evaluation of their growth rate through removal of $100 \mathrm{~cm}^{2}$ of colonies of each species. Palythoa caribaeorum and Zoanthus sociatus had similar growth rates, and both species grew faster than Protopalythoa variabilis. The recolonization strategy seems to differ among species. The contact fringes between $P$. caribaeorum and $Z$. sociatus remained unchanged over time, without any type of aggressive interaction between them, suggesting that stand-off was the strategy used by these organisms. Palythoa caribaeorum and $Z$. sociatus grew among the polyps of $P$. variabilis, often killing its colonies. The coexistence of zoanthids reveals a capacity for survival in the face of competition for limited resources such as free substrate, which led to the colonization and establishment of zoanthids in intertidal environments.
\end{abstract}

\section{RESUMO}

A competição por espaço é comum em organismos sésseis que vivem em substrato consolidado. Os corais apresentam muitas estratégias para competição por espaço, incluindo danos ao oponente ou inibição do crescimento. No presente estudo, as interações competitivas entre três espécies de zoantídeos foram investigadas em um ambiente de recifes de arenito no nordeste brasileiro. As habilidades competitivas dos zoantídeos foram analisadas por observações periódicas das margens de contato entre as colônias em ambiente natural e avaliação experimental da taxa de crescimento, através da remoção de uma área de $100 \mathrm{~cm}^{2}$ de colônias de cada espécie. Palythoa caribaeorum e Zoanthus sociatus apresentaram taxa de crescimento similar, crescendo mais rápido que Protopalythoa variabilis. A estratégia de colonização parece ser diferente entre as espécies. As margens de contato entre $P$. caribaeorum e $Z$. sociatus permaneceram inalteradas ao longo do tempo, sem qualquer interação agressiva entre as colônias, sugerindo que a inibição do crescimento foi a estratégia utilizada. Palythoa caribaeorum e $Z$. sociatus cresceram entre os pólipos de $P$. variabilis, muitas vezes sufocando e matando suas colônias. A coexistência entre os zoantídeos revela uma capacidade de sobrevivência frente a recursos limitados, como substrato livre, o que levou ao sucesso na colonização e estabelecimento de zoantídeos em ambientes intertidais.

Descriptors: Zoanthids, Competition, Growth rate, Coexistence.

Descritores: Zoantídeos, Competição, Taxa de crescimento, Coexistência.

\section{INTRODUCTION}

Interspecific interactions are one of the factors that can affect the structure of biological communities (SANDIN; MCNAMARA, 2012).
Among them, predation and competition for space play a major role in distribution (TANNER, 1997) and strongly influence community structure and species diversity on marine hard substrates, particularly those with encrusting forms. Hard substrate available for settlement and growth is a limited resource for sessile 
invertebrates that are known for competing for space during their growth (SHEPPARD, 1985). Amongst cnidarians, those that form colonies tend to compete for space, promoting contact with neighboring colonies and generating diverse responses (RINKEVICH, 2004). During the interactions among cnidarians, particularly corals, many competitive processes, some of them poorly understood, occur at morphological, cellular and biochemichal levels, as, for example, the discharge of nematocysts, the development of mesenterial filaments and sweeper tentacles, allelopathic interactions, stand-off and growth over the opponent, the latter being one of the most common and well registered competition mechanisms (FRANK et al., 1995; CONNELL et al., 2004). The direct contact between colonies of cnidarians sometimes results in aggressive responses that can interrupt the growth of both competitors and their competitive coexistence (CORNELL; KARLSON, 2000).

Previous studies have investigated competition processes among many invertebrates such as sponges (ABDO et al., 2008; LUTER; DUCKWORTH, 2010), ascidians (SHENKAR; LOYA, 2008; SHENKAR et al., 2008), Bryozoans (TURNER; TODD, 1994) and cnidarians (LANG, 1973; JACKSON; BUSS, 1975; SHEPPARD, 1979, 1985; KARLSON, 1980; SAMMARCO et al., 1985; SHEPPARD, 1985; DAI, 1990; ROMANO, 1990; CHADWICK, 1991; ALINO et al., 1992; FRANK et al., 1995; BASTIDAS; BONE, 1996; VAN VEGHEL et al., 1996; RINKEVICH; SAKAY, 2001; CONNELL et al,. 2004; RINKEVICH, 2004). In Brazil there is a lack of studies reporting the competition between corals. Only the studies of Maida et al. (1995) have described the competition among Brazilian corals.

Although of great ecological significance, there are few studies on the competitive ability and the settling capacity of antozoans on the rocky reefs of the Atlantic tropical intertidal zones. Thus, this study seeks to investigate the mutually competitive strategies adopted by three species of zoanthids: Palythoa caribaeorum (Duchassaing; Michelotti, 1860), Protopalythoa variabilis (Duerden, 1898) and Zoanthus sociatus (Ellis, 1767) in a rocky reefs environment in northeastern Brazil, thus clarifying the degree of dominance among them, determining the growth rate of these species and analyzing their capacity to recolonize a free substrate. The competitive strategies and rate of reinvasion of these species through natural competition were checked by non-manipulative observation and a manipulative experiment by scraping the competing colonies and observing their ability to recolonize, with a view to ascertaining their mutually competitive abilities and their ability to colonize a disturbed habitat.
Knowledge of the competitive strategies of zoanthids and the competitive interactions between them as also between them and other organisms is of great importance in the understanding of the community dynamics of marine hard substrates, providing useful insights for future monitoring and conservation projects of the marine biota.

\section{Material and Methods}

\section{Study Site}

The coastal region of northeastern Brazil is composed of a diversity of habitats such as rocky reefs, sandy beaches and dunes. The rocky reefs have a tabular format, slope gently seaward and consist of sand cemented by calcium carbonate and iron oxide (MORAIS et al., 2009). The study area was the Paracuru Beach, located in the Northeast of Brazil (0323'53.0' 'E, 3900'38.8' 'W) (Fig.1), with a $3 \mathrm{~km}$ stretch of reef which is only fully exposed at low tide. The study site is characterized by many species of sessile invertebrates such as anemones, starfish, mollusks, sponges, ascidians, hydrozoans and crustaceans (MATTHEWS-CASCON; LOTUFO, 2006), although there is little diversity of hard corals, which appear in small colonies along the reef. However, there is a great abundance of zoanthids, that form large colonies on the hard substrate. The study site is the only area on the Ceará coast where zoanthids are found in great abundance and in direct contact with each other.

\section{Growth Rate}

In order to measure the growth rates, 100 $\mathrm{cm}^{2}$ of living tissue was removed from 10 randomly chosen colonies of each species, during low tide. The colonies chosen were situated approximately $5 \mathrm{~m}$ apart and were of the same size; they were removed with the help of scalpels and spatula from the central region of the respective colony. The colonies were marked with stainless colored wire to facilitate their location during growth monitoring. The regrowth of the colonies over the scraped areas was checked using a $10 \times 10 \mathrm{~cm}$ quadrat subdivided by nylon threads into 100 squares, each one of $1 \mathrm{~cm}^{2}$, totaling $100 \mathrm{~cm}^{2}$ of sampling area. The quadrat was placed over the scraped areas and the number of squares completely covered by the zoanthid during its growth was registered monthly for 250 days to a total of 7 samples per species. The polyps in each experimental area were counted and their diameters measured with a vernier caliper. 


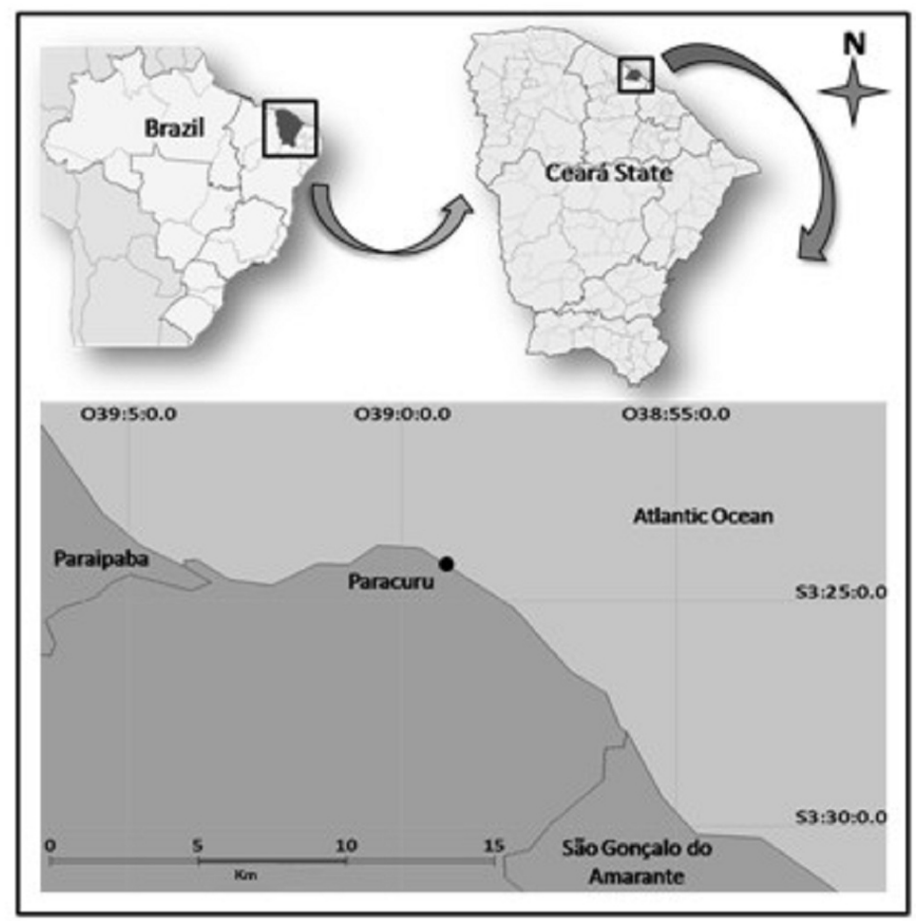

Fig. 1. Northeastern Brazil map showing the study site, Paracuru Beach, Ceará State.

Competitive Interactions Among Zoanthids

In order to analyze the competitive interactions among the species of zoanthids, we analyzed the natural competition between them by means of a non-manipulative experiment. Ten areas of contact between colonies of each pair-wise combination of the three species were randomly chosen and marked - to a total of 30 samples. The sites were marked with four stainless steel nails forming a quadrat $(10 \times 10 \mathrm{~cm})$ and each contact area was photographed monthly for 8 months. According to Bastidas and Bone (1996), who undertook a similar experiment, this time is sufficient to ascertain how the contact margins between the two species concerned have changed. A $100 \mathrm{~cm}^{2}$ quadrat subdivided by nylon threads into 100 squares was placed over the contact areas during the photographic shots. The nails guaranteed that the quadrat was placed in the same position for each successive sample. The photographs were later analyzed to determine the changes that had occurred in the contact margin and the competitive capability of each of the species concerned.

Data Analysis

The mean growth rate of zoanthids was calculated for each species based on two parameters: square centimeters per month and number of polyps per month. The growth rate was plotted in relation to the time necessary to carry through the regression analysis and the exponential or linear adjustment for each species. The data were checked for independence, homoscedasticity, and usually normal distribution. Thus one-way analysis of variance (ANOVA), followed by Tukey's test, were carried through for the comparison of the growth rates of the three species of zoanthids in relation to the area and the number of polyps per month. Graph Pad Prism. 4.0 software was used to construct the boxwhisker on the basis of the descriptive variables of the experiment. Statistical analysis was performed with a significance level of $5 \%$.

\section{RESULTS \\ Growth Rate}

The three species quickly responded to the experimental scraping by growing out from the edges of the scraped area. The areas denuded of the three species decreased over time and the species thus presented effective recolonization capability. Palythoa caribaeorum and Zoanthus sociatus were the first to fully recolonized the experimental area. By the end of the experiment, $P$. caribaeorum and $Z$. sociatus 
had recolonized almost the whole experimental area with respective coverage of $92.1 \pm 6.1 \mathrm{~cm}^{2}$ and $88.2 \pm$ $9.9 \mathrm{~cm}^{2}$. During this time, Protopalythoa variabilis had only recolonized $47.7 \pm 6.4 \mathrm{~cm}^{2}$ of the scraped area (Fig. 2).

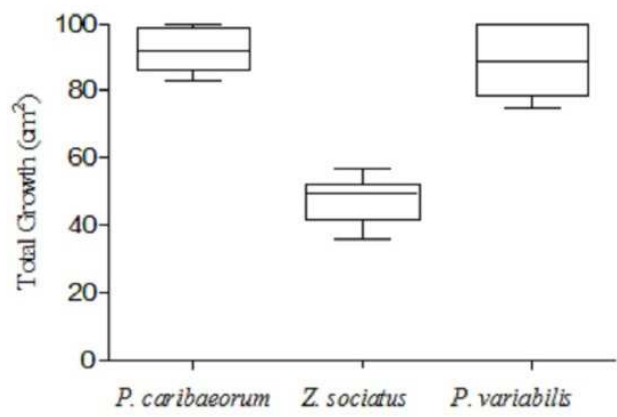

Fig. 2. Total growth of Palythoa caribaeorum, Zoanthus sociatus and Protopalythoa variabilis after 8 months of experiment. The line inside the boxes represents the mean and the bars show the standard deviation.

There was no statistically significant difference between the growth rates of $P$. caribaeorum and $Z$. sociatus $(\mathrm{P}>0.05)$, but these two species presented a significantly higher growth rate than $P$. variabilis $(\mathrm{P}<0.001)$.

Palythoa caribaeorum grew an average 11.0 $\mathrm{cm}^{2} /$ month and seemed to have a higher initial growth which tended to stabilize over time (Fig. 3). Zoanthus sociatus grew at an average rate of $10.6 \mathrm{~cm}^{2} /$ month and presented a pattern of growth rate similar to Palythoa caribaeorum (Fig. 4). Protopalythoa variabilis grew at an average rate of $5.74 \mathrm{~cm}^{2} /$ month. This species had a linear growth, instead of the exponential growth that characterized the other two species, and had the slowest growth rate (Fig. 5).

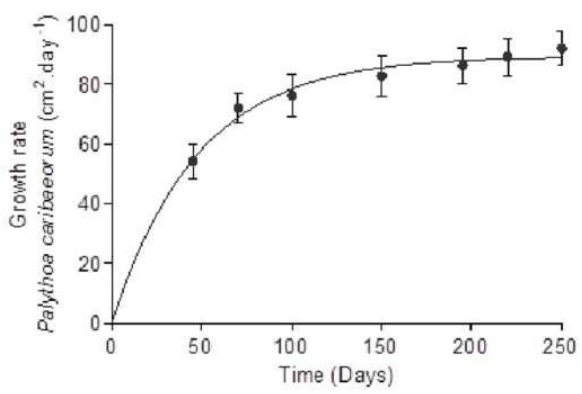

Fig. 3. Mean monthly growth rate $\left(\mathrm{cm}^{2}\right)$ of Palythoa caribaeorum on the Paracurú Beach (NE, Brazil) along 8 months. The circle represents the mean and the bars show standard deviation.

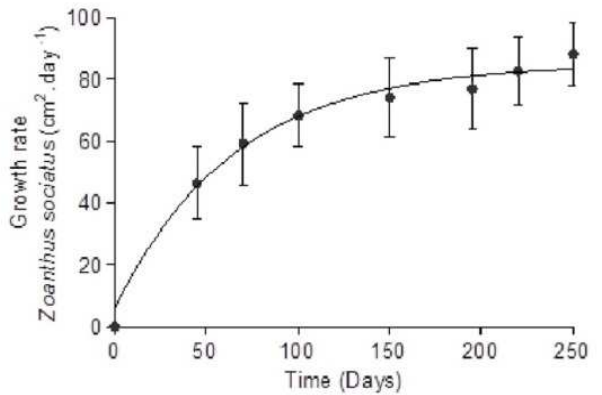

Fig. 4. Mean monthly growth rate $\left(\mathrm{cm}^{2}\right)$ of Zoanthus sociatus on the Paracurú Beach (NE, Brazil) along 8 months. The circle represents the mean and the bars show standard deviation.

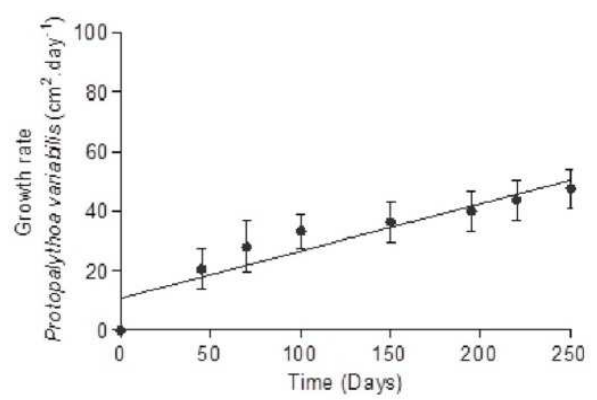

Fig. 5. Mean growth rate $\left(\mathrm{cm}^{2}\right)$ of Protopalythoa variabilis on the Paracuru Beach (NE, Brazil) along 8 months. The circle represents the mean and the bars show standard deviation.

The monthly growth rates of the three species were compared, both in relation to the area occupied and to the number of polyps (Table 1). The mean diameter of the polyp of $P$. variabilis was significantly larger than those of $P$. caribaeorum and $Z$. sociatus. However, the space occupation capacity of $P$. variabilis was smaller than those of the other two species.

Table 1. Growth rates of the three zoanthid species in relation to the area occupied $\left(\mathrm{cm}^{2} / \mathrm{month}\right)$ and the number of polyps per month. The symbol * represents statistically similar values.

\begin{tabular}{lllc}
\hline \hline Growth Rate & P. caribaeorum & P. variabilis & Z. sociatus \\
$\mathrm{cm}^{2} /$ month & $11.05 \pm 0.74^{*}$ & $5.94 \pm 0.77$ & $10.65 \pm 1.2^{*}$ \\
$\mathrm{n}^{\circ}$. polyps/month & $52.8 \pm 3.5^{*}$ & $28.4 \pm 3.7$ & $50.7 \pm 5.7^{*}$ \\
\hline
\end{tabular}

\section{Competitive Interaction Among Zoanthids}

The contact areas between Z. sociatus and $P$. caribaeorum remained unchanged throughout the study period, suggesting that these species stop their growth when they come into contact with each 
other (Fig. 6). On the other hand, both Z. sociatus and $P$. caribaeorum grew into the spaces between the polyps of $P$. variabilis, suggesting that the latter is a weaker competitor (Fig. 7). Moreover, the morphology of the $P$. variabilis colony probably facilitates invasion by $Z$. sociatus and $P$. caribaeorum due to the spaces between its polyps. It was observed over time that the latter two species suffocate polyps of $P$. variabilis, often killing them and occupying the free space thus left between them.

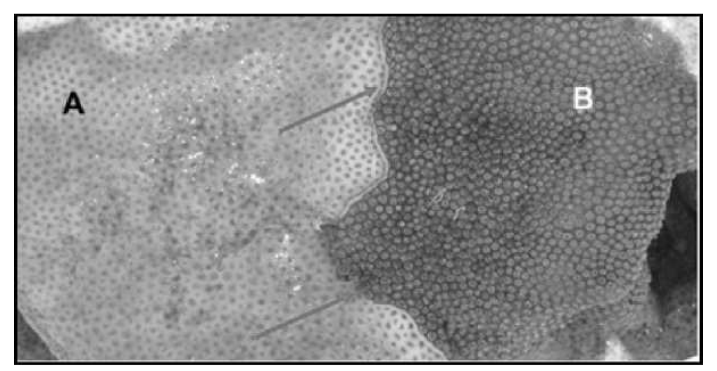

Fig. 6. Contact margin (arrows) showing "Stand- off" among Palythoa caribaeorum (A) and Zoanthus sociatus (B).

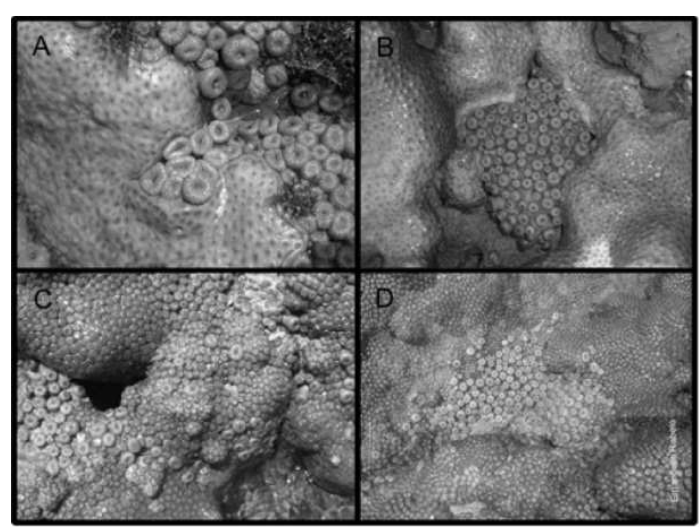

Fig. 7. (A, B) Colony of Palythoa caribaeorum growing around polyps of Protopalythoa variabilis; (C, D) Colony of Zoanthus. sociatus growing around polyps of Protopalythoa. variabilis.

\section{DisCUSSION}

Our experiments showed that zoanthid species are able to recolonize a cleared area in a few months. In the present study, $P$. caribaeorum and $Z$. sociatus presented similar growth rates, while $P$. variabilis grew more slowly.

Bastidas and Bone (1996) and Suchaneck and Green (1981) have reported that $P$. caribaeorum presented a higher growth rate than other zoanthid species; however, we have ascertained that $P$. caribaeorum presents a growth rate similar to that of $Z$. sociatus and higher than that of $P$. variabilis. The growth rate of Zoanthus sociatus found in the present study was similar to those found for the same species by Sebens (1982) and Karlson (1988). According to Karlson (1988), Z. sociatus has a high regenerative capacity in response to disturbances in the substratum, shadow, transplantation and predation and that it presents changes in the size of the polyps, phototrophic growth and capacity of regeneration of the colony when in unfavorable microhabitats. Of the species studied here, $P$. caribaeorum and $Z$. sociatus seem to be those with the highest capacity of occupation of empty substratum and $P$. variabilis seems to be that with the least. There are no previous studies describing the growth of $P$. variabilis, this being the first to report on the grow rate of this zoanthid.

Our results show that the pattern of growth of zoanthid species varies. Palythoa caribaeorum and $Z$. sociatus growing discontinuously and $P$. variabilis presenting continuous growth.

Some authors relate the competitive capacity of coral species to their growth rates. For example, Sheppard (1979) found that the most aggressive species are those which grow fast. Dai (1990) observed that the most aggressive species are generally those best able to grow on other species and therefore constitute the major components of coral reefs in the Indo-Pacific. Connell et al. (2004) verified that the growth of coral colonies is affected by competition. According to these authors, competitively superior species tend to grow faster than inferior species. The results of this present study suggest that $P$. caribaeorum and $Z$. sociatus have the highest growth rates whereas $P$. variabilis presents the lowest growth rate. Thus, according to the hypothesis that fast-growing species are competitively superior, apparently $P$. caribaeorum and $Z$. sociatus are superior competitors and $P$. variabilis the weakest competitor. However, some authors defend that generally species of slow growth are more aggressive than those of fast growth. Lang (1973) observed that the most aggressive species found on the Jamaican coast are those with low growth rates. Connell et al. (2004) suggested that some species with low growth rate mobilize their energy for competition. Competition reduces growth, as the competitive processes use energy that could contribute to growth, leading to a decline in the growth rate. The apparently lower competitive capacity of $P$. variabilis verified in the present study corroborates the hypothesis by which species of low growth have inferior competition capability. However, long-term studies on zoanthid competition at other sites are called for to confirm this results.

Polyp size is another parameter used to analyze competitive capacity between cnidarians. According to Van Veghel et al. (1996), differences in 
the morphologic characteristics between the species probably play an important role in competitive interactions. Abelson and Loya (1999) found a positive correlation between the oral disc diameter and the aggression capacity, suggesting that the size of the polyp has some influence on competitive ability. This influence has not been confirmed by this present study, because the largest polyp diameter was presented by $P$. variabilis, the competitively inferior zoanthid species. This was evidenced by the absence of any competitive strategy on the part of $P$. variabilis when in contact with the other zoanthid species studied. It would have been expected that zoanthids with larger polyps would occupy free spaces faster through budding, considering that a larger polyp can occupy more space. Nevertheless, in this study, the species with the largest polyps, $P$. variabilis, presented a smaller capacity of occupation of free space than the other species with smaller polyps. The low speed of recolonization of $P$. variabilis could be due to the high energy cost involved in the growing of big polyps, leading to slower growth. According to Fine and Loya (2003), the rate at which a colony might grow to occupy new or newly cleared space on a substratum is highly dependent on how the modules are arranged (i.e. the growth mode), by how much energy is required to generate new modules (for example polyp size or complexity), and by how easily energetic resources can be mobilized towards the area of growth. Thus, a large polyp probably requires more energy, taking longer to grow than small polyps, which grow faster.

The results in terms of natural competition found in the present study corroborate the hypothesis suggested by Sheppard (1979) that fast-growing species are more aggressive. Protopalythoa variabilis, the apparently slow-growing species, seems to be a weaker competitor for space than the other two species, as it did not offer resistance to the growth of $P$. caribaeorum and $Z$. sociatus in the spaces among its polyps, which frequently led to a colony's death. There were no previous studies on the competitive strategy of $P$. variabilis, this present one being the first to demonstrate the weak competitive capability of this species when coexisting with other zoanthids.

In our study we verified that growth inhibition or stand-off was the strategy used by $P$. caribaeorum and $Z$. sociatus. The interruption of the growth on the contact edges, or stand-off, is a common mechanism adopted by corals (DAI, 1990; BAK et al., 1982; KARLSON, 1980; LANG 1973)

According to Karlson (1978), the growth inhibition as well as stand-off interactions are usual strategies in the competition for space. Karlson (1988) found that growth inhibition and stand-off interactions in species of zoanthids, are defensive strategies adopted in their competition for space on marine hard substrates. Palythoa caribaeorum is a notoriously aggressive competitor for space, and has been documented as overgrowing a number of other scleractinian corals in studies undertaken at numerous locations (SUCHANEK; GREEN 1981; BASTIDAS; BONE 1996). However, no aggressive interaction such as the drawing of mesenterial filaments or growing over the opponent, as some authors have registered for many species of soft corals, was observed between the zoanthid species in this study. The mechanism observed among $P$. caribaeorum and $Z$. sociatus was stand-off with interruption of their growth at the contact edges between their colonies. The contact margins between $P$. caribaeorum and $Z$. sociatus showed no modification during the period of study, there being no degree of competitive dominance between them, thus agreeing with the results found by Bastidas and Bone (1996) in a similar experiment. These latter authors in a study in Venezuela had verified that the edges of contact between $P$. caribaeorum and $Z$. sociatus had remained unchanged over time, suggesting that growth inhibition was the strategy of coexistence adopted by these species. In other words, these species might be showing competitive equivalence that limits movement of the inter-colonial boundaries.

Zoanthids are known to have a special ability to compete for space through allelopathy, i.e the direct inhibition of one species by another using toxic substances (SAMMARCO et al., 1985). These animals produce large quantities of structurally interesting and biologically active substances and, because they are relatively vulnerable to predation, the accumulation of secondary metabolites is possibly related to defense mechanisms (HARPER et al., 2001). Palytoxin is a substance found in members of the genus Palythoa and is considered the most potent and toxic biologically active marine molecule known, and only less poisonous than botulinum toxin (KAUL et al., 1974). Although biochemical studies on the genus Palythoa are abundant, studies on other zoanthid genera such as Protopalythoa and Zoanthus are still poorly documented. Thus, studies on biochemical and biological activity could elucidate the competitive ability of these animals through the study of substances produced during allelopathy.

The coexistence between the zoanthids reveals a survival capacity in the face of competition for limited resources which enables the species to succeed in settling and establishing themselves in intertidal environments. The strategy displayed by the zoanthid species permits them to coexist in such a way as to maintain a balance in their use of space. Knowledge of zoanthid ecology is still restricted to a few species, and additional studies are needed in order to improve the understanding of the dynamics and the competitive behavior of these animals. 


\section{REFERENCES}

ABDO, D. A.; MCDONALD, J. I.; HARVEY, E. S; FROMONT, J.; KENDRICK G. A. Neighbour and environmental influences on the growth patterns of two temperate Haliclonid sponge. Mar. Freshwater. Res. v.59, n. 4, p. 304-312, 2008

ABELSON A.; LOYA, Y. Interspecific aggression among stony corals in Eilat, Red Sea: A hierarchy of aggression ability and related parameters. Bull. Mar. Sci., v. 3, n. 65, p. 851-860, 1999.

ALINO, P. M.; SAMMARCO, P. W.; COLL, J. C. Competitive strategies in soft corals (Coelenterata, Octocorallia). IV. Environmentally induced reversals in competitive superiority. Mar. Ecol. Prog. Ser., v. 81, p. 129-145, 1992.

BAK, R. P. M.; TERMAAT, R. M.; DEKKER, R. Complexity of coral interactions: Influence of time, location of interaction and epifauna. Mar. Biol., v. 69, p. 215-222, 1982.

BASTIDAS, C.; BONE, D. Competitive strategies between Palythoa caribaeorum and Zoanthus sociatus (Cnidaria:Anthozoa) at a reef flat environmental in Venezuela. Bull. Mar. Sci., v. 59, n. 3, p. 543-555, 1996.

CHADWICK, N. E. Spatial distribution and the effects of competition on some temperate Scleractinia and corallimorpharia. Mar. Ecol.Prog. Ser., v. 70, p. 39-48, 1991.

CONNELl, J. H.; HUGHeS, T. P.; WALlaCe, C. C.; TANNER, J. E.; HARMS, K. E.; KERR, A. M. A longterm study of competition and diversity of corals. Ecol. Monogr., v. 74, n. 2, p. 179-210, 2004

CORNELL, H. V.; KARLSON, R. H. Coral species richness: ecological versus biogeographical influences. Coral Reefs, v. 19, p. 37-49, 2000.

DAI, C. Interspecific competition in Taiwanese corals with special reference to interactions between alcyonaceans and scleratinians. Mar. Ecol. Prog. Ser., v. 60, p. 291297, 1990

FINE, M.; LOYA, F. Alternate coral-bryozoan competitive superiority during coral bleaching. Mar. Biol., v. 142, p. 989-996, 2003.

FRANK, U.; BRICKNER, I.; RINKEVICH, B.; LOYA, Y.; BAK, R. P. M.; ACHITUV, Y.; ILAN, M. Allogeneic and xenogeneic interaction in reef-building corals may induce tissue growth without calcification. Mar. Ecol. Prog. Ser., v. 124, p. 181-188, 1995.

HARPER, M. K.; BUGNI, T. S.; COPP, B. R.; JAMES, R. D.; LINDSAY, B. S.; RICHARDSON, A. D.; SCHNABEL, P. C.; TASDEMIR, D.; VANWAGONER, R. M.; VERBITSKI, S. M.; IRELAND, C. M Introduction to the Chemical Ecology of Marine Natural Products in J. B. McClintock and B. J. Baker (eds.), Marine Chemical Ecology, Boca Raton: CRC Press, 2001, pp. 3-69.

JACKSON, J. B. C.; BUSS, L. Allelopathy and spatial competition among coral reef invertebrates. Proc. Nat. Acad. Sci., n. 12, v. 72, p. 5160-5163, 1975.

KARLSON, R. H. Predation and space utilization patterns in a marine epifaunal community. J. Exp. Mar. Biol. Ecol., v. 31 , p. $225-239,1978$
KARLSON, R. H. Alternative competitive strategies in a periodically disturbed habitat. Bull. Mar. Sci., v. 30, n. 4, p. 894-900, 1980.

KARLSON, R. H. Size-dependent growth in two zoanthid species: a contrast in clonal strategies. Ecology, v. 69, n. 4, p. 1219-1232, 1988.

KAUL P. N.; FARMER M. R.; CIERESZKO L. S. Pharmacology of palytoxin: The most potent marine toxin known. P. W. Pharmacol. Soc., v. 17, p. 294, 1974.

LANG, J. Interspecific aggression by scleractinian corals. 2: Why the race is not only to the swift. Coral Reefs, v. 23, n. 2, p.260-279, 1973.

LUTER, H. M.; DUCKWORTH, A. R. Influence of size and spatial competition on the bioactivity of coral reef sponges. Biochem. Syst. Ecol., v. 38, p. 146-153, 2010.

MAIDA, M.; SAMMARCO, P. W.; COLL, J. C. Effects of soft corals on scleractinian coral recruitment. I. Directional allelopathy and inhibition of settlement. Mar. Ecol.Prog. Ser., v. 121, p. 191-202, 1995.

MATTHEWS-CASCON, H., LOTUFO, T. M. C. Biota marinha da costa oeste do Ceará. Brasília: Ministério do Meio Ambiente, 2006. 248 p.

MORAIS, J. O.; IRION, G. F.; PINHEIRO, L. S.; KASBOHM, J. Preliminary results on Holocene sealevel changes on Ceara coast / Brazil. J. Coast. Res., v. 56, p. 646-649, 2009.

RINKEVICH, B.; SAKAI, K. Interspecific interactions among spacies of the coral genus Porites from Okinawa, Japan. Zoology, v. 104, p. 91-97, 2001

RINKEVICH, B. Allorecognition and xenorecognition in reef corals: a decade of interactions. Hydrobiologia, v. 530531, p. 443-450, 2004.

ROMANO, S. L. Long-term effects of interspecific aggression on growth of the reef-building corals Cyphastrea ocelina (Dana) and Pocillopora damicornis (Linnaeus). J. Exp. Mar. Biol. Ecol, v. 140, p. 135-146, 1990.

SAMMARCO, P. W.; COLL J. C.; BARRE, S. L. Competitive strategies of soft corals (Coelenterate: Octocorallia). II. Variable defensive responses and susceptibility to Secleractinian corals. J. Exp. Mar. Bio. Ecol., v. 91, p. 199-215, 1985.

SANDIM, S. A.; MCNAMARA, D. E. Spatial dynamics of benthic competition on coral reefs. Oecologia, v. 168, p. 1079-1090, 2012.

SEBENS, K. P. Intertidal distribuition of Zoanthids on the Caribbean Coast of Panama: Effects of predation and desiccation. Bull. Mar. Sci., v. 32, n. 1, p. 316-335, 1982.

SHENKAR, N.; LOYA, Y. The solitary ascidian Herdmania momus: native (Red Sea) versus non-indigenous (Mediterranean) populations. Biol. Invasions, v. 10, n. 8, p. 1431-1439, 2008.

SHENKAR, N.; BRONSTEIN, O.; LOYA, Y. Population dynamics of a coral reef ascidian in a deteriorating environment. Mar. Ecol. Progr. Ser., v. 367, p. 163171, 2008.

SHEPPARD, C. R. C. Interspecific aggression between reef corals with reference to their distribution. Mar. Ecol. Progr. Ser., v. 1, p. 237-247, 1979. 
SHEPPARD, C. R. C. Unoccupied substrate in the central Great Barrier Reef: role of coral interactions. Mar. Ecol. Progr. Ser., v. 25, p. 259-268, 1985.

SUCHANEK, T. H.; GREEN, D. J. Interspecific competition between Palythoa caribaeorum and other sessile invertebrates on St. Croix Reefs, U.S. Virgin Islands. INT. CORAL REEF SYMP., 4. Proc..., v. 2, p. 679684, 1981.

TANNER, J. E. The effects of density on the zoanthid Palythoa caesia. J. An. Ecol., v. 66, p. 793-810, 1997.

TURNER, S. J.; TODD, C. D. Competition for Space in encrusting bryozoan assemblages: the influence of encounter angle, site and year. J. Mar. Biol. Assoc. UK, v. 74, . 3, p. 603-622, 1994.
VAN VEGHEL, M. L. J. CLEARY, D. F. R.; BAK, R. P. M. Interspecific interactions and competitive ability of the reef-building coral Montastrea annularis. Bull. Mar. Sci., v. 58, n. 3, p. 792-803, 1996.

(Manuscript received 27 August 2012; revised 03 February 2013; accepted 04 February 2013) 